\title{
Relationship Between Obesity and Liver Enzymes Levels in Turner's Syndrome
}

\author{
Farzaneh Rohani ${ }^{\mathrm{a}, \mathrm{b}}$, Fatemeh Golgiric ${ }^{\mathrm{c}}$, Mohammad Reza Alaeid, g, Mojgan Karimie, \\ Parham Nikraftar ${ }^{\mathrm{f}}$, Ramin Bozorgmehr ${ }^{\mathrm{f}}$
}

\begin{abstract}
Background: Liver enzyme abnormalities have been reported in Turner's syndrome (TS). There are some studies about possible causes of abnormal levels of liver enzymes. One of the main suggestions is obesity. The study aimed to determine the relationship between obesity and liver enzymes levels in patients with TS.
\end{abstract}

Methods: Forty-one karyotype-proven TS patients referred to Endocrinology and Metabolism Research Center were included in this cross-sectional study. Height and weight of patients were measured and their body mass index (BMI) was calculated. The patients were divided into two groups as the control group including 27 cases $(65.8 \%)$ with normal BMI (defined as $<85$ th percentile for age and gender), and the overweight group including 14 cases (34.2\%) (defined as BMI $>85$ th percentile for age and gender). Serum levels of aspartate transaminase (AST), alanine transaminase (ALT) and alkaline phosphatase $(\mathrm{AlkPh})$ were measured.

Results: There were no statistically significant differences regarding AST $(27 \pm 2.7$ vs. $29.6 \pm 5.85 \mathrm{U} / \mathrm{L} ; \mathrm{P}=0.3)$, ALT $(20.1 \pm 2.45$ vs. $22.2 \pm 5.85 \mathrm{U} / \mathrm{L} ; \mathrm{P}=0.5)$, and AlkPh (583.4 \pm 2.45 vs. $472.8 \pm 161.5$ $\mathrm{U} / \mathrm{L} ; \mathrm{P}=0.28$ ) between overweight TS patients and those with normal BMI.

Conclusion: There was no significant difference in liver enzyme levels between TS patients with normal BMI and those who were overweight.

Keywords: Turner's syndrome; Liver enzymes; Obesity; Overweight

Manuscript accepted for publication January 30, 2017

aPediatric Growth and Development Research Center, Institute of Endocrinology and Metabolism, Iran University of Medical Science, Tehran, Iran

${ }^{\natural}$ Department of Endocrinology and Metabolism, Ali-Asghar Children's Hospital, Iran University of Medical Sciences, Tehran, Iran

'Endocrine Research Center, Institute of Endocrinology and Metabolism, Iran University of Medical Sciences, Tehran, Iran

¿Department of Pediatric Endocrinology and Metabolism, Mofid Children's Hospital, Shahid Beheshti University of Medical Sciences, Tehran, Iran ${ }^{\mathrm{e}}$ General Physician, Iran University of Medical Sciences, Tehran, Iran fIran University of Medical Sciences, Tehran, Iran

${ }^{\text {g}}$ Corresponding Author: Mohammad Reza Alaei, Department of Pediatric Endocrinology and Metabolism, Mofid Children's Hospital, Shahid Beheshti University of Medical Sciences, Tehran, Iran. Email: Alaee2003@yahoo.com

doi: https://doi.org/10.14740/gr778w

\section{Introduction}

Turner's syndrome (TS) was first detected by Ullrich in an 8-year-old German girl and then described by Henry Turner in $1938[1,2]$. TS is the most common sex chromosome abnormality in female gender and occurs approximately in 50 per 100,000 live births $[3,4]$. TS is defined by a complete or partial (includes the tip of its short arm) omission of one X chromosome in females [5,6]. Prominent clinical features of TS are gonadal insufficiency and short stature [7]. Abnormalities in glucose metabolism, lipid metabolism, liver enzymes, and thyroid function tests have been reported in patients with TS and should be checked out at 2-year intervals [8-13]. Elevation of liver enzymes was reported in adults with a fivefold increase in the risk of cirrhosis [14-16]. Liver enzymes abnormalities have been suggested to have relationships with hormone therapy, autoimmunity or obesity $[17,18]$. TS patients are predisposed to obesity $[4,19]$, partly because of low physical fitness and a sedentary lifestyle $[14,20]$.

Therefore, the objective of this study was to assess relationship between obesity and liver enzymes level in TS patients.

\section{Materials and Methods}

\section{Study subjects}

All 41 karyotype-proven participants of this cross-sectional study were selected from TS patients who were referred to the Endocrinology and Metabolism Research Center of Iran University of Medical Sciences. After taking detailed history about hepatic disease symptoms, cigarette smoking, alcohol drinking, and drug history, the patients with known hepatic disease and/or history of taking medications with hepatotoxic effects were excluded.

\section{Study measurements}

Demographic profiles including age, weight, height and body mass index $\left(\mathrm{BMI}=\right.$ weight $(\mathrm{kg}) /$ height $\left.(\mathrm{m})^{2}\right)$ were gathered. The heights of all patients were measured by Harpenter stadiometer and for measuring their weight, we used a digital scale. All patients were examined physically for the size of the liver. The subjects were divided into two groups including 
Table 1. Demographic Variables of Turner's Patients With Normal BMI and Overweight Patients

\begin{tabular}{llllll} 
& Age at the time of diagnosis, years & Age at the time of study, years & Height, $\mathbf{c m}$ & Weight, $\mathbf{k g}$ & \multicolumn{1}{c}{ BMI, $\mathbf{k g} / \mathbf{m}^{2}$} \\
\hline Normal BMI & $14.54 \pm 5.85$ & $16.66 \pm 7.15$ & $130 \pm 26.23$ & $35.815 \pm 14.01$ & $19.63 \pm 3.42$ \\
Overweight & $9.34 \pm 6.11$ & $19.22 \pm 5.04$ & $129 \pm 17.47$ & $41.86 \pm 13.90$ & $24.40 \pm 3.22$ \\
\hline
\end{tabular}

Data are presented as mean \pm SD.

overweight (patients with BMI $>85$ th percentile for sex and age) and normal weight (patients with BMI $<85$ th percentile for sex and age). A $1.5 \mathrm{~mL}$ venous fasting blood sample was taken and kept in the sterile EDTA containing test tubes at -70 ${ }^{\circ} \mathrm{C}$. All samples were transferred to laboratory of Endocrine Research Center for measuring serum concentration of liver enzymes, including aspartate transaminase (AST), alanine transaminase (ALT) and alkaline phosphatase (AlkPh). Reference values were 35,40 , and $150 \mathrm{IU} / \mathrm{L}$ for AST, ALT and $\mathrm{AlkPh}$, respectively $[21,22]$. In patients with elevated liver enzymes, the tests were done for the second time. For subjects that the second test confirmed elevated levels of liver enzymes, liver ultrasonography, serologic test for viral hepatitis (HBsAg, anti-HCV antibody), autoantibodies (anti-smooth muscle antibody (anti-SMA), anti-nuclear antibody (ANA), and anti-liver-kidney microsome (LKM) antibody), $\alpha 1$-antitrypsin, anti-endomysial antibody, triglyceride, cholesterol, glucose, urine copper and urine ceruloplasmin were done. This study was approved by the ethics committee of Endocrine Research Center (Firuzgar). Informed consent was obtained from parents and children of appropriated age. Human right was respected in accordance with the Helsinki Declaration.

\section{Statistical analysis}

The data were analyzed using SPSS software version 13.0 for Windows (SPSS Inc., Chicago, IL, USA). Comparison of liver enzyme values between normal and overweight patients was performed using the independent $t$-test. The results reported as mean \pm standard deviation (SD). The P-values less than 0.05 were considered significant and a power of $80 \%$ was considered in the analysis. All reported P-values were two-tailed. Also for multivariable analysis, linear regression was performed between liver enzymes and BMI, age, age of diagnosis weight and height.

\section{Results}

Forty-one patients were included in our study. Mean ( \pm SD) age, height and weight were $16.69 \pm 6.86$ years, $129.21 \pm$ $24.16 \mathrm{~cm}$ and $37.73 \pm 13.94 \mathrm{~kg}$, respectively. The anthropometric data of the two groups are given in Table 1. Mean $( \pm$ $\mathrm{SD}$ ) age at the time of diagnosis was $12.09 \pm 6.44$ years. None of the patients had history of smoking or drinking.

Mean $\left( \pm\right.$ SD) BMI was $21.20 \pm 4.05 \mathrm{~kg} / \mathrm{m}^{2}$. Distribution of BMI is shown in Figure 1. According to age and sex-matched standard BMI curve, the patients were divided into two groups as control group including 27 subjects $(65.8 \%)$ with normal BMI (i.e., BMI $<85$ th percentile) and case group including
14 subjects $(34.2 \%)$ who were overweight $(\mathrm{BMI}>85$ th percentile). Of those, 28 cases $(68.2 \%)$ had monosomic pattern (45XO) according to their karyotype while others karyotypes were mosaicism or isochromosome $(45 \mathrm{XO} / 46 \mathrm{XX}$ in six subjects $(13.6 \%), 45 \mathrm{XO} / 46 \mathrm{XY}$ in three subjects $(6.6 \%), 46 \mathrm{Xi}(\mathrm{X})$ (q10) in three subjects $(6.6 \%)$, and $45 \mathrm{XO} / 44$ in one patient $(2.2 \%))$. Only two cases had elevated liver enzymes. One of them had extrahepatic biliary atresia and after therapeutic surgery, the enzymes level returned to the normal range. Another patient was a 14-year-old girl with a height of $136.5 \mathrm{~cm}$ and a weight of $49 \mathrm{~kg}$. The enzyme elevation showed a progressive pattern over 8 months $(\mathrm{AST}=77 \mathrm{U} / \mathrm{L} \rightarrow 139 \mathrm{U} / \mathrm{L}$ and $\mathrm{ALT}=$ $126 \mathrm{U} / \mathrm{L} \rightarrow 201 \mathrm{U} / \mathrm{L}$ ). Paraclinical investigations were normal. Liver biopsy showed steatohepatitis. The patient's BMI in the time of liver enzyme elevation was 26.3 which increased to 28.4 when the enzymes level returned to normal range. We were unable to explain the cause of liver abnormality in this patient.

The two above mentioned patients were excluded. Mean $( \pm \mathrm{SD})$ liver enzyme levels in overweight patients were AST $=$ $27 \pm 5.4 \mathrm{U} / \mathrm{L}, \mathrm{ALT}=20.1 \pm 4.9 \mathrm{U} / \mathrm{L}$, and AlkPh $=583.4 \pm 269$ $\mathrm{U} / \mathrm{L}$. In those with normal BMI, the figures were AST $=29.6$ $\pm 11.7 \mathrm{U} / \mathrm{L}, \mathrm{ALT}=22.2 \pm 11.7 \mathrm{U} / \mathrm{L}$, and $\mathrm{AlkPh}=472.8 \pm 323$ U/L. There were no significant differences between patients with normal BMI and those who were overweight regarding serum liver enzymes levels. P values were 0.34 for AST, 0.52 for ALT and 0.28 for AlkPh.

In linear regression model for AST, ALT and AlkPh with age, BMI, height, weight and age of diagnosis, the R squares were $0.28,0.17$ and 0.48 , respectively. The significance for all variables were higher than 0.05 except for age at the time of diagnosis and serum level of AlkPh (Sig. = 0.002). On the other hand, our multivariable analysis showed that in the relationship of other variables, the age of diagnoses was the only variable that was associated with higher level of AlkPh. This finding confirms that the alkaline phosphatase is age-dependent in pediatric patients.

The BMI and weight had not significant association with liver enzymes (for AST, $\mathrm{P}=0.521$ and 0.492 ; ALT, $\mathrm{P}=0.955$ and 0.659 and $\mathrm{AlkPh}, \mathrm{P}=0.964$ and 0.697 , respectively).

\section{Discussion}

Our study about association of obesity and liver enzymes level in TS showed no significant relation between obesity and serum liver enzymes level. TS actually is a multi-organ disease and the affected patients have various complications as the result of their illness and need very exact follow-up and good management. One of the organs which might be involved is 


\section{BMI}
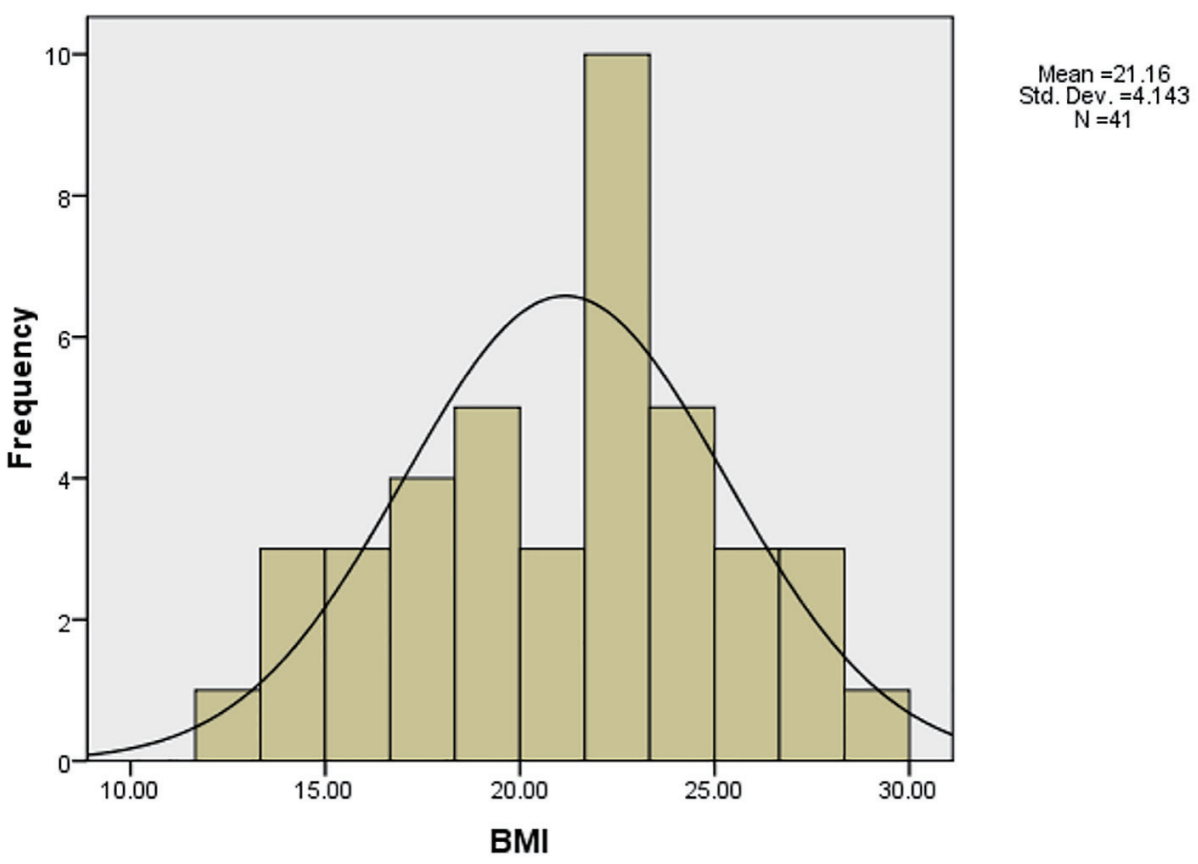

Figure 1. Distribution of BMI in study population.

the liver. In our TS patients, one case had extrahepatic biliary atresia (a rare condition), and one overweight patient (BMI = 26.3) had steatohepatitis.

The causes suggested for liver enzymes abnormalities in TS include hormone therapy and autoimmunity [17, 18, 23]. Obesity, which is a characteristic feature of girls with TS [23], is discussed as one of the causes of liver involvement [24-27] in TS which could be presented by elevated liver enzyme levels.

Based on our study, no relationship was seen between obesity and liver enzyme levels. This finding is in accordance with earlier studies in this field [17, 28, 29]. El-Mansoury et al followed 218 adult Turner's patients for 5 years. Seventy-nine $(36 \%)$ of their patients showed elevated levels in one or more liver enzymes at start, and another $23 \%$ of patients had developed elevated liver enzymes during a 5-year follow-up. In their study, the patients who had enzymes elevation had higher BMI, triglyceride, cholesterol level compared to those with normal liver enzymes level. But only the total cholesterol level could play as a significant predictor for liver enzymes elevation. In their study, elevated liver enzymes were more common in patients with age between 26 and 45 years old [28]. Our study showed low frequency of abnormal liver function in young TS patients which is in contrast to the high incidence of liver function abnormality in adult TS patients (like ElMansoury et al's study), suggesting that long-term hormone therapy or worsening or long-term obesity may be related to the development of abnormal liver function in some TS patients. In another study, Larizza et al followed two groups of Turner's patients, 22 patients with raised liver enzymes (group
A) and 48 patients with normal enzymes level (group B) for a period of $0.8-21.9$ years [23]. They found hepatitis $C$ and autoimmunity as the causes of liver enzyme elevation in some cases of group A patients. Weight excess standard deviation scores (SDS) were significantly higher in Turner patients with liver enzyme elevation. So authors concluded, although an autoimmune pathogenesis might be considered in some cases, weight excess seems the most frequent cause of increased liver enzymes in TS. In Wasniewska et al's study of 214 TS patients younger than 20 years, only $19(8.9 \%)$ had elevated liver enzymes in 2 years follow-up. According to results of this study, authors concluded that both obesity and autoimmunity are not frequently involved in the etiology of TS liver abnormality [29]. Salerno et al monitored liver enzymes level in 70 patients with TS for a mean period of $7.6 \pm 4.2$ years. They observed increased liver enzyme in 14 out of 70 patients $(20 \%)$. In the majority of cases (10/14), it was drug-related, in two cases it was autoimmunity-related, and in one case it was cryptogenic. Although obesity was a frequent finding, it was considered the cause of liver abnormality only in one patient [17].

Our study had a potential limitation. The small sample size could be as a limitation in our study, so we suggest a larger cohort study for determining the exact role of obesity in the changes of liver enzymes level in TS patients.

\section{Conclusion}

There was no statistically significant difference regarding liver enzyme levels (AST, ALT, and AlkPh) between normal BMI 
and overweight TS teenagers. In other words, obesity may not be a cause for difference in terms of serum liver enzyme levels abnormalities. In addition, no relationship was seen between obesity and liver enzymes level.

\section{Acknowledgments}

We would like to thank Dr. Khamseh, chief, as well as medical staff of Endocrine Research Center for kind support and cooperation. This study was part of MD thesis of MS. Dr. Mojgan Karimi approved by Tehran University of Medical Sciences (TUMS).

\section{Grant Support}

This work was also supported by grant no. 202 from Endocrinology and Metabolism Research Center affiliated to IUMS.

\section{References}

1. Turner HH. A syndrome of infantilism, congenital webbed neck, and cubitus valgus. Endocrinology. 1938;23:566 . [Abstract].

2. Ullrich O. Turner's syndrome and status bonnevie-ullrich; A synthesis of animal phenogenetics and clinical observations on a typical complex of developmental anomalies. Am J Hum Genet. 1949;1(2):179-202.

3. Robinson A. Demography and prevalence of Turner syndrome. In: Rosenfeld RG, Grumbach MM, (Eds). Turner syndrome. New York: Marcell Dekker. 1990; p. 93-100.

4. Hall JG, Gilchrist DM. Turner syndrome and its variants. Pediatr Clin North Am. 1990;37(6):1421-1440.

5. Savendahl L, Davenport ML. Delayed diagnoses of Turner's syndrome: proposed guidelines for change. J Pediatr. 2000;137(4):455-459.

6. Cools M, Drop SL, Wolffenbuttel KP, Oosterhuis JW, Looijenga LH. Germ cell tumors in the intersex gonad: old paths, new directions, moving frontiers. Endocr Rev. 2006;27(5):468-484.

7. Collett-Solberg PF, Gallicchio CT, Coelho SC, Siqueira RA, Alves ST, Guimaraes MM. Endocrine diseases, perspectives and care in Turner syndrome. Arq Bras Endocrinol Metabol. 2011;55(8):550-558.

8. Radetti G, Mazzanti L, Paganini C, Bernasconi S, Russo G, Rigon F, Cacciari E. Frequency, clinical and laboratory features of thyroiditis in girls with Turner's syndrome. The Italian Study Group for Turner's Syndrome. Acta Paediatr. 1995;84(8):909-912.

9. Gravholt CH, Juul S, Naeraa RW, Hansen J. Morbidity in Turner syndrome. J Clin Epidemiol. 1998;51(2):147-158.

10. Gravholt $\mathrm{CH}$, Naeraa RW, Fisker S, Christiansen JS. Body composition and physical fitness are major determinants of the growth hormone-insulin-like growth factor axis aberrations in adult Turner's syndrome, with important modulations by treatment with 17 beta-estradiol. J
Clin Endocrinol Metab. 1997;82(8):2570-2577.

11. Gravholt CH, Naeraa RW, Nyholm B, Gerdes LU, Christiansen E, Schmitz O, Christiansen JS. Glucose metabolism, lipid metabolism, and cardiovascular risk factors in adult Turner's syndrome. The impact of sex hormone replacement. Diabetes Care. 1998;21(7):1062-1070.

12. Gravholt $\mathrm{CH}$, Christian Klausen I, Weeke J, Sandahl Christiansen J. Lp(a) and lipids in adult Turner's syndrome: impact of treatment with 17beta-estradiol and norethisterone. Atherosclerosis. 2000;150(1):201-208.

13. Sylven L, Hagenfeldt K, Brondum-Nielsen K, von Schoultz B. Middle-aged women with Turner's syndrome. Medical status, hormonal treatment and social life. Acta Endocrinol (Copenh). 1991;125(4):359-365.

14. Landin-Wilhelmsen K, Bryman I, Wilhelmsen L. Cardiac malformations and hypertension, but not metabolic risk factors, are common in Turner syndrome. J Clin Endocrinol Metab. 2001;86(9):4166-4170.

15. Elsheikh M, Hodgson HJ, Wass JA, Conway GS. Hormone replacement therapy may improve hepatic function in women with Turner's syndrome. Clin Endocrinol (Oxf). 2001;55(2):227-231.

16. Gravholt CH. Medical problems of adult Turner's syndrome. Horm Res. 2001;56(Suppl 1):44-50.

17. Salerno M, Di Maio S, Gasparini N, Rizzo M, Ferri P, Vajro P. Liver abnormalities in Turner syndrome. Eur J Pediatr. 1999;158(8):618-623.

18. Donaldson MD, Gault EJ, Tan KW, Dunger DB. Optimising management in Turner syndrome: from infancy to adult transfer. Arch Dis Child. 2006;91(6):513-520.

19. Suwa S. Standards for growth and growth velocity in Turner syndrome. Acta Paediatr Jpn. 1992;34:206-220.

20. Gravholt CH, Lauridsen AL, Brixen K, Mosekilde L, Heickendorff L, Christiansen JS. Marked disproportionality in bone size and mineral, and distinct abnormalities in bone markers and calcitropic hormones in adult turner syndrome: a cross-sectional study. J Clin Endocrinol Metab. 2002;87(6):2798-2808.

21. Ijaz B, Ahmad W, Javed FT, Gull S, Hassan S. Revised cutoff values of ALT and HBV DNA level can better differentiate $\mathrm{HBeAg}(-)$ chronic inactive $\mathrm{HBV}$ patients from active carriers. Virol J. 2011;8:86.

22. Han J, Yong B, Luo C, Tan P, Peng T, Shen J. High serum alkaline phosphatase cooperating with MMP-9 predicts metastasis and poor prognosis in patients with primary osteosarcoma in Southern China. World J Surg Oncol. 2012;10:37.

23. Larizza D, Locatelli M, Vitali L, Vigano C, Calcaterra V, Tinelli C, Sommaruga MG, et al. Serum liver enzymes in Turner syndrome. Eur J Pediatr. 2000;159(3):143-148.

24. Bernasconi S, Larizza D, Benso L, Volta C, Vannelli S, Milani S, Aicardi G, et al. Turner's syndrome in Italy: familial characteristics, neonatal data, standards for birth weight and for height and weight from infancy to adulthood. Acta Paediatr. 1994;83(3):292-298.

25. Franzese A, Vajro P, Argenziano A, Puzziello A, Iannucci MP, Saviano MC, Brunetti F, et al. Liver involvement in obese children. Ultrasonography and liver enzyme levels at diagnosis and during follow-up in an Italian popula- 
tion. Dig Dis Sci. 1997;42(7):1428-1432.

26. Golik A, Rubio A, Weintraub M, Byrne L. Elevated serum liver enzymes in obesity: a dilemma during clinical trials. Int J Obes. 1991;15(12):797-801.

27. Luyckx FH, Desaive C, Thiry A, Dewe W, Scheen AJ, Gielen JE, Lefebvre PJ. Liver abnormalities in severely obese subjects: effect of drastic weight loss after gastroplasty. Int J Obes Relat Metab Disord. 1998;22(3):222226.
28. El-Mansoury M, Berntorp K, Bryman I, Hanson C, Innala E, Karlsson A, Landin-Wilhelmsen K. Elevated liver enzymes in Turner syndrome during a 5-year follow-up study. Clin Endocrinol (Oxf). 2008;68(3):485-490.

29. Wasniewska M, Bergamaschi R, Matarazzo P, Predieri B, Bertelloni S, Petri A, Sposito M, et al. Increased liver enzymes and hormonal therapies in girls and adolescents with Turner syndrome. J Endocrinol Invest. 2005;28(8):720-726. 